\title{
Bセッション 日本内科学会生涯教育講演会
}

\section{平成 25 年度}

\section{6. メタボリックシンドロームと慢性腎臓病 (CKD) \\ 伊藤 裕}

Key words : メタボリックシンドローム, CKD, インスリン抵抗性, 心腎連関

1.メタボリックドミノ：メタボリックシ ンドローム (metabolic syndrome : Mets) 一慢性腎臓病 (chronic kidney disease : CKD)-心血管病 (cardiovascular disease : CVD) の流れ

メタボリックドミノの流れにおいて, 内臓脂 肪蓄積，インスリン抵抗性をベースにしたMets はCKDを惹きおこし，CKDは末期腎不全 (endstage kidney disease : ESKD)のみならず, CVD のリスクとなる(心腎連関) (図 1). Mets-CKDCVDの流れにおける病態把握は, “臓器連関”と “臓器の時間”の臨床概念から捉える事が重要で あると思われる。わたしは，この二つの概念を とりいれた新しい医療の考え方として「時空医 療」というコンセプトを示している1).

Mets患者のCKD発症率は非Mets患者の 2 倍で ある. CKDの原因疾患としては, Metsを構成す る高血圧や糖尿病などの生活習慣病以外にも腎 炎などがあるが，透析導入の原疾患として，糖 尿病性腎症，腎硬化症は増加の一途をたどり， 一方腎炎による導入は減少している.さらにCVD 発症リスクは前者の方が明らかに高い. CKD
診療ガイドライン 2013 においても, CKDの重症 度分類は, C (cause：原因), G(GFR：腎機能), $\mathrm{A}$ (アルブミン尿) で評価するとしており, 原疾 患はCKDの予後において重要である.

腎硬化症や糖尿病性腎症に加え「肥満関連腎 症Obesity-related glomeronephropathy : ORG」 も最近注目されている. ORGは, 巣状分節性糸 球体硬化症と糸球体肥大を呈し，一部の患者で はネフローゼ症候群を認め, 決して予後の良い 疾患ではない.

このように, メタボリックシンドロームを構 成する病態の中で起こってくるCKDは患者予後 に深刻な影響を及ぼす。

\section{CKD発症におけるMetsの位置づけ}

$\mathrm{CKD}$ 重症度分類のGおよびAはそれぞれ独立し たCKDの増悪因子となる. 加齢に伴い, 腎疾患 の有無にかかわらず, Gは直線的に低下し $(-0.3$ $\mathrm{ml} /$ 分/年), $\mathrm{CKD}$ の割合は確実に増加し, 80 から 90 歳では男性では $50 \%$ 近く, 女性では $70 \%$ 近くに達する。まさに腎蔵は, 我々の老化を告 げる“時計”であり，また心腎連関等を介して， 他の臓器の老化スピードを決定する“ペースメー

慶應義塾大学腎臓内分泌代謝内科

Programs for Continuing Medical Education : B session ; 6. Metabolic syndrome and chronic kidney disease.

Hiroshi Itoh : Division of Endocrinology, Metabolism and Nephrology, Department of Internal Medicine, Keio University School of Medicine, Japan. 


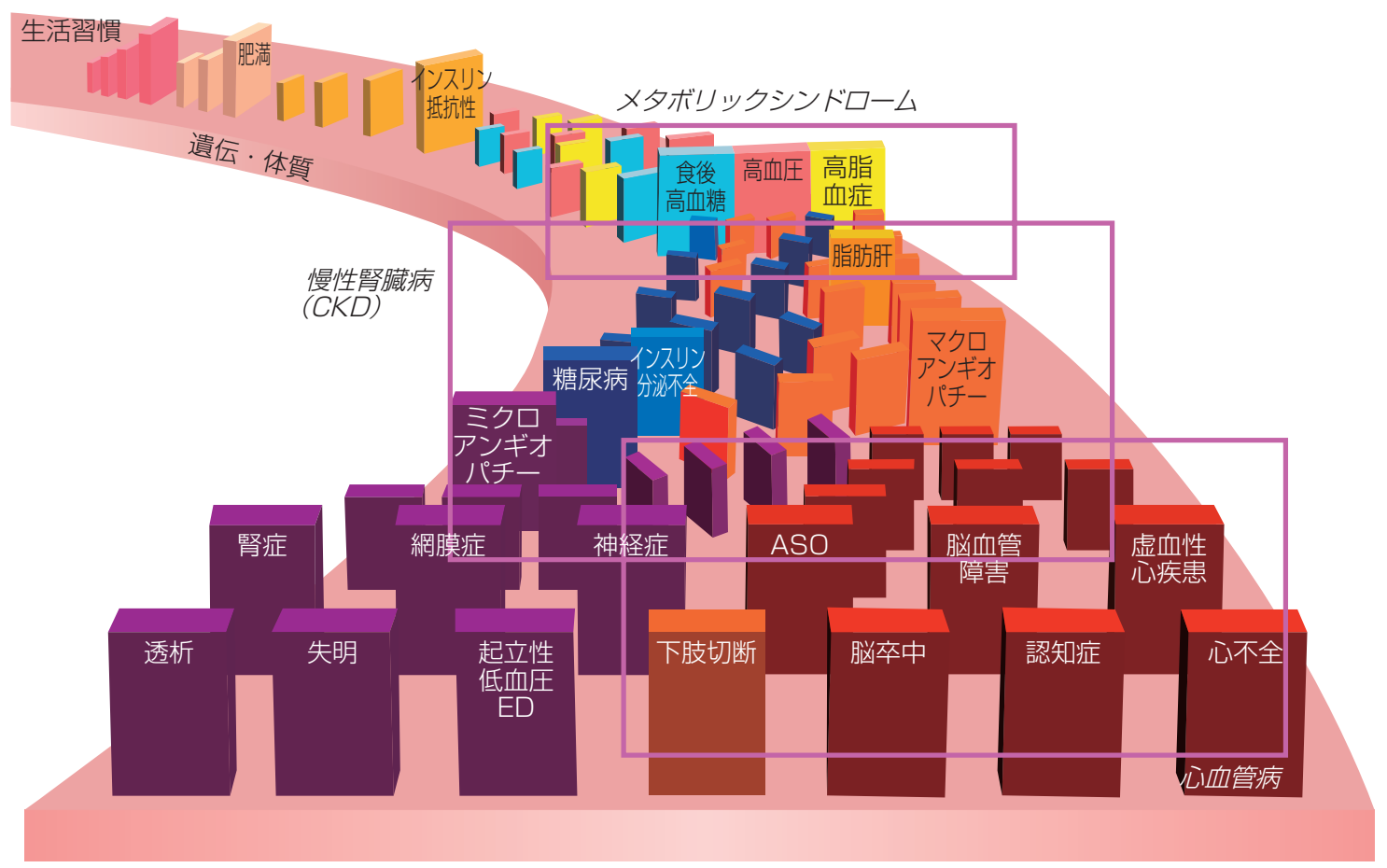

図 1.メタボリックドミノの流れにおけるメタボリックシンドロームとCKD

カー蔵器”とも捉えられる ${ }^{2)}$.

図 2 は, 我々の教室で検討した様々な疾患患 者の腎ドップラー検査の結果であるが, 加齢と ともに腎血管抵抗は増加し，腎血管抵抗とGFR は負の相関を示す。すなわち, 特定の疾患にか ぎらず，「腎虚血」は，腎老化において共通の病 因となる。この腎虚血を進める大きな要因が高 血圧であり，高血圧は，老化を刻む腎臓の時計 の針を進ませる（ $-4 \sim 8 \mathrm{ml} /$ 分/年).

Gは腎蔵内の内皮障害, 炎症による腎微小循環 障害と糸球体高血圧, 過剩濾過による腎機能障 害の程度を反映する，高血圧症がその最も重要 な決定因子となる。こうした変化は, 傍䯣質系 球体を形成する輸入動脈( “strain vessel”) から始 まる.我々はこのstrain vesselsのリモデリングが 高血圧発症に重要であること, さらにこのプロ セスには腎内レニン・アンジオテンシン系の活 性化が重要であることを報告した.

脳卒中易発症性高血圧自然発症ラット (spon- taneously hypertensive rats-stroke prone: SHR-SP) は, 血圧が $200 \mathrm{mmHg}$ 以上となり, 脳 卒中を起こして死亡する高血圧モデル動物であ る. 我々は, このSHR-SPの高血圧発症前の段階 において, ACE阻害片あるいはアンジオテンシ ン受容体拮抗薬：ARBを投与し, 血圧の上昇を 抑えておくと，その後これらレニンアンジオテ ンシン系阻害薬の投与を中止しても, その後の 血圧の上昇が抑えられ, ラットは死亡しないこ とを見出だした ${ }^{3)}$.さらに, 高血圧が発症した後 でも，その初期であれば，レニンアンジオテン シン系を抑制することにより高血圧を治療する と, その後投薬を止めても, 高血圧は再発しない ことも明らかにした(高血圧の退行regression) ${ }^{4}$. SHR-SPの高血圧発症早期には，すでに， strain vesselsの肥厚が生じており, この変化は一過性 のレニンアンジオテンシン系の阻害により元に 戻ることを観察した.こうした動物実験結果は, 高血圧発症には重要な時期critical periodがあり, 

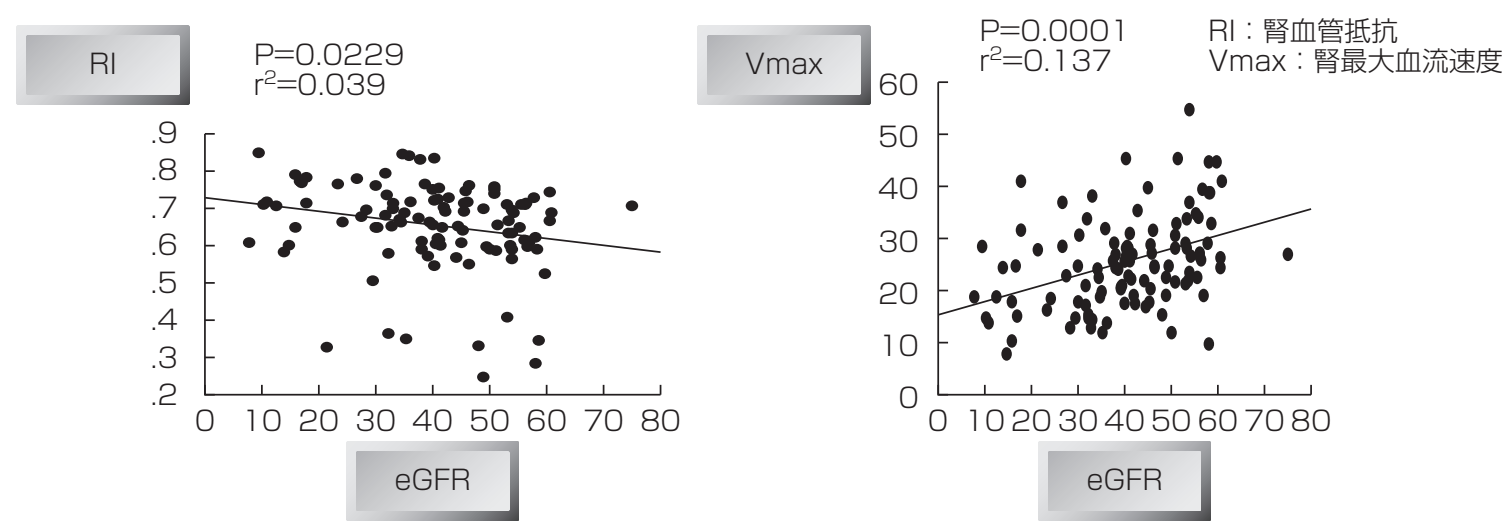

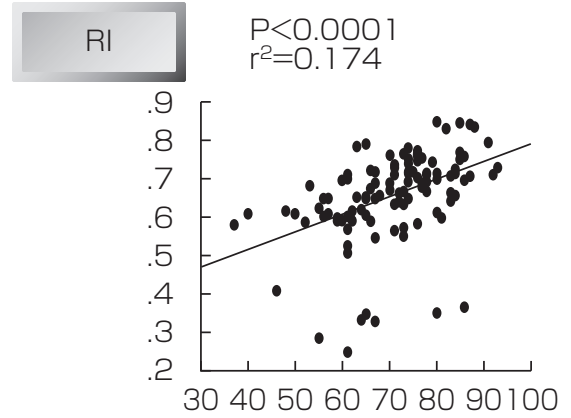

年齢

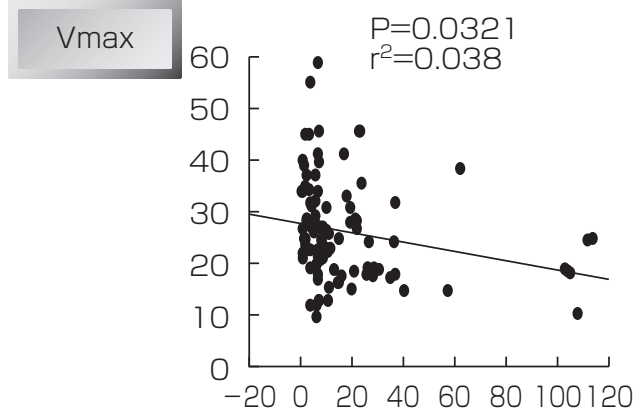

$\alpha 1-$ ミクグロブリン / Cr

図 2. 腎ドップラー検査で評価した, CKD患者での腎血行動態とeGFRの関係

その時期においてレニンアンジオテンシン系が 活性化することでstrain vesselsが肥厚し, 高血圧 発症につながることを示唆している。このよう に，腎機能障害と高血圧の発症進展は相互に影 響を及ぼしあうと考えられる。また，一時的な レニンアンジオテンシン系抑制の治療介入であっ てもその効果が残存する可能性が示され, 我々 はこの現象を“レニンアンジオテンシンブロッ クメモリー”と呼んでいる.

一方, Aに関しては糸球体のスリット機能およ び近位尿細管の再吸収能の障害が重要である. 糖尿病性腎症においては, これまでは糸球体障 害が注目されてきたが，最近我々は，ミトコン ドリアの豊富な近位尿細管の代謝障害がまず起 こり, その結果, 糸球体の足細胞の機能低下が
生じる可能性を示した(尿細管一ポドサイトコミュ ニケーション)(図 3).

すなわち, 我々はサーチュインと呼ばれる分 子に注目した、下等動物からサルを含む高等動 物まで, 7 割から 8 割のカロリー制限により寿命 が延長することが知られているが，サーチュイ ンは, NAD依存性脱アセチル化酵素であり，こ のカロリー制限による寿命延長の責任分子であ る. サーチュインはヒトではSirt1〜 7 が知られて いるが, Sirt1 は尿細管, 足細胞に発現しており, 高血糖により，まず尿細管のSirt1 発現が低下す る. その結果, 尿細管からのニコチン酸代謝産 物の分泌が減少する。その減少により足細胞の Sirt1 発現が低下し, 接着分子Claudin1の発現が 上昇し, 糸球体スリット機能が障害されてアル 


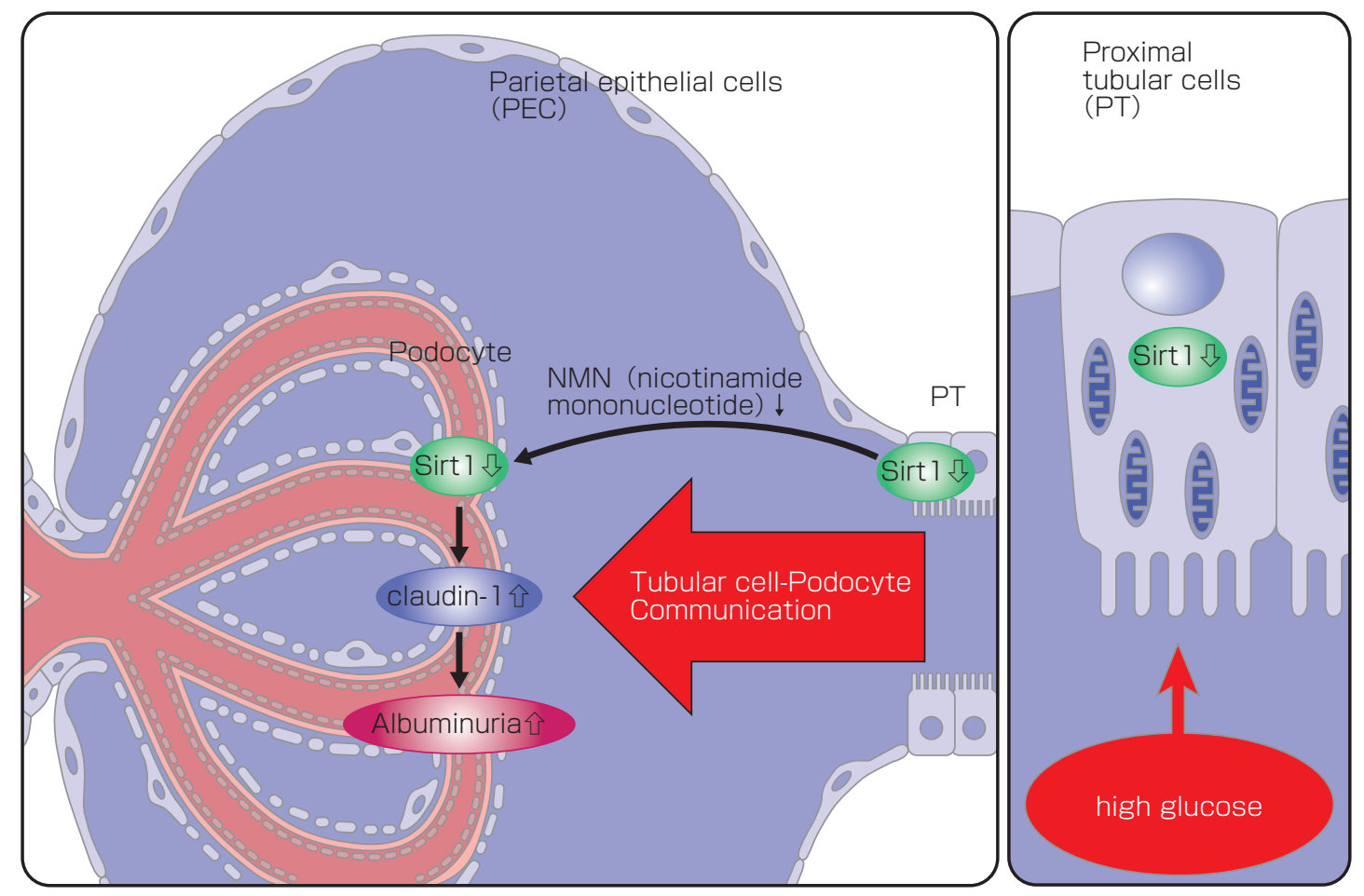

図 3. 糖尿病性腎症発症における尿細管一ポドサイトコミュニケーションの障害の意義 5

ブミン尿が出現することを我々は報告した.

糖尿病性腎症ではこのように時間の経過の中 で, 腎臓内の細胞間の代謝障害とそのダイナミッ クなコミュニケーションが大切であると考えら れる。

\section{3. 臓器連関における “ペースメーカー臓 器”としての腎臓の役割}

腎臓の障害は他の臓器の障害にも大きな影響 を及ぼし(蔵器連関), 腎臓は, 全身の臓器老化 のペースを決定する “ペースメーカー”臓器と なる。このような臓器連関においては, 神経を 介した情報伝達が重要である。メタボリックシ ンドロームでは食塩感受性高血圧が高率に認め られるが，これは肥満に伴う腎神経活性の立進 が重要であることが従来より知られていた。す なわちMets患者では, 腎機能障害の進行に伴う $\mathrm{NaCl}$ 排泄障害が起こるよりはるかに早い段階で,
腎神経活動立進の結果生じる $\mathrm{NaCl}$ 再吸収の上昇 により食塩感受性高血圧がもたらされる.

最近，この腎神経活性立進の高血圧における 意義が，難治性高血圧症に対する腎神経除神経 術という新しい治療オプションにより証明され た.この治療法は, 患者大腿動脈よりカテーテ ルを進め, 腎動脈に到達させ, 血管内空から高 周波レーザーにより，動脈外側の腎神経を焼灼 するというものである。この治療法はこれまで 良好な治療成績が報告されている。この治療法 施行後全身の交感神経活性が低下することが観 察された。この効果は, 腎臓から脳に向かう迷 走神経求心路の遮断によりもたらされたと考え られる。すなわち, 腎臓から発せられ脳に伝え られる迷走神経求心路を介した情報が血圧決定 に大きな役割を演じるということが示されたの である(腎脳連関).

インスリン抵抗性は, MetsさらにCKDの流れ を推し進めるが, 我々は逆にCKDがインスリン 
表. CKD患者各ステージにおける血圧, 耐糖能, 脂質の比較

\begin{tabular}{l|c|c|c|c}
\hline \multicolumn{1}{c|}{ Parameter } & Stage 1 & Stage 2 & Stage 3 & Stage 4and5 \\
\hline $\mathrm{n}$ (男性/女性) & 19 & 89 & 78 & 14 \\
\hline 年齢 & 53.4 & 61.1 & 66.1 & 72.6 \\
\hline $\mathrm{BMl}$ & 23.6 & 22.2 & 23.6 & 22.7 \\
\hline 収縮期血圧 $(\mathrm{mmHg})$ & 128.9 & 133.4 & 135.5 & 137.1 \\
\hline 拡張期血圧 $(\mathrm{mmHg})$ & 73 & 76.1 & 78.3 & 76.1 \\
\hline $\mathrm{eGFR}\left(\mathrm{ml} / \mathrm{min} / 1.73 \mathrm{~m}^{2}\right)$ & 106.1 & 72.3 & 45.7 & 17.6 \\
\hline $\mathrm{Hb}(\mathrm{g} / \mathrm{dl})$ & 13.1 & 13.4 & 13.3 & 11.5 \\
\hline $\mathrm{LDL}-\mathrm{C}(\mathrm{mg} / \mathrm{dl})$ & 121.1 & 123.9 & 112.9 & 115.4 \\
\hline $\mathrm{TG}(\mathrm{mg} / \mathrm{dl})$ & 95.6 & 135.5 & 131.9 & 164.4 \\
\hline 血糖值 $(\mathrm{mg} / \mathrm{dl})$ & 101.1 & 103.4 & 106.7 & 108 \\
\hline インスリン濃度 $(\mu \mathrm{U} / \mathrm{ml})$ & 8.38 & 9.98 & 10.87 & 19.07 \\
\hline $\mathrm{HOMA-IR}$ & 2.166 & 2.632 & 3.004 & 5.063 \\
\hline
\end{tabular}

抵抗性を更に進行させるという病態に注目して いる．表は, 我々の教室で経験した患者につい て各CKDステージと臨床パラメータをまとめた ものである. BMIは, CKDステージ間に明らか な差は認めなかったが, 血圧および空腹時血糖 は, CKDステージが進むごとに上昇傾向を示し た。また，CKDステージが上昇するにつれて， インスリンのクリアランスの低下により血中イ ンスリン值の上昇が認められた。 インスリン濃 度の上昇にもかかわらず, 空腹時血糖が上昇傾 向を示し,インスリン抵抗性指数HOMA-IRの上 昇が認められた。 eGFRは, HOMA-IRと血中イ ンスリン濃度と有意な相関を認めた。またイン スリン抵抗性の上昇を反映して, 中性脂肪の増 加を認めた。この結果は, $\mathrm{CKD}$ 進展に伴いイ ンスリン抵抗性が進行することを示唆している.

我々は, 動物実験により, 腎機能の障害によ りインスリン抵抗性が生じることを確認してお り,これらの結果は, $\mathrm{CKD}$ そのものがインスリ ン抵抗性を悪化させる “腎性インスリン抵抗性 症候群; Renal insulin resistance syndrome: RIRs”という病態を示している.

我々は最近非糖尿病CKD患者について, 持続 ブドウ糖モニタリングContinuous Glucose Moni- toring Sysytemで一日の血糖の変動を検討したと ころ, CKD群では健常人に比較して, 食後の血 糖上昇が著しく，一日血糖変動が大きいことを 観察した.

また，我々は，CKDにおいて認められるイン スリン抵抗性が, 腎機能の低下を推し進める因 子であるのか, あるいはその進行を予測するマー カーになるかに関して, 前向きにCKD患者をフォ ローアップしたところ，観察開始時のインスリ ン抵抗性が強い患者群でその后 3 年間での腎機 能の低下が大きいことが明らかとなった。 この ことは，CKDに伴うインスリン抵抗性が，更に CKDを悪化させる可能性を示しており，また， CKDの予後を判定するバイオマーカーになり得 ることを示唆している.

一般的に肥満は心血管イベントのリスクとさ れるが, 末期腎不全患者では, “太ることができ ない”患者が多く，これらの患者の生命予後は 逆に悪い事が知られている（いわゆるreverse epidemiology).この病態におけるRIRsの関与が 想定される.

腎不全保存期における, 尿毒素, たとえばイ ンドキシル硫酸の腎不全, CVD, 骨代謝異常に おける意義は臨床的に明らかにされているが, 


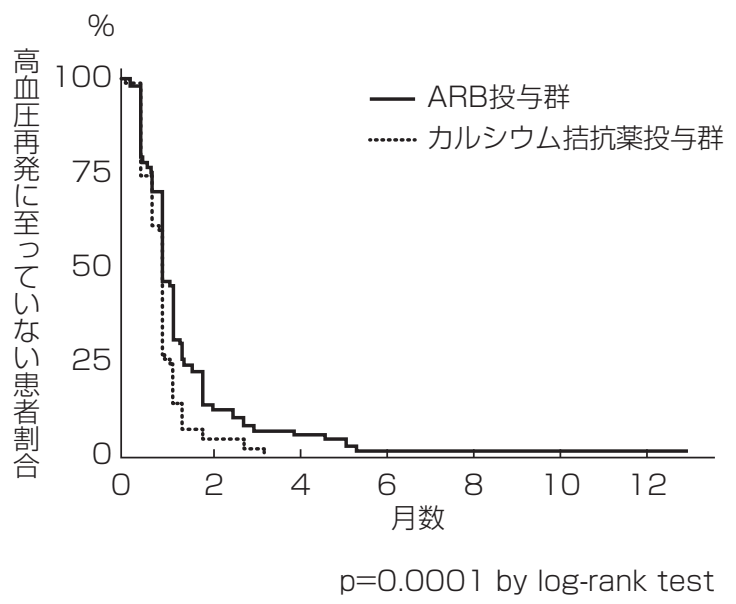

図 4. 軽症高血圧患者へのARB，カルシウム拮 抗薬投与中止後の高血圧再発の経過

早期のCKDにおいても, 腎臓に関連した液性因 子の変調は, RIRsの病態生理において重要であ る.内因性一酸化窒素 (NO) の拮抗物質である ADMA（asymmetrical dimethyl arginine）は腎 不全において増加し予後と相関することが知ら れている. 最近我々は, ADMAがインスリン分 泌の制御に関わる可能性を明らかにした6).また, RIRsではCKDに伴い脂肪細胞においてインスリ ン抵抗性が生じる（腎脂肪連関）が, 動物実験 によりこの病態において, 我々はアルドステロ ン・ミネラルコルチコイド受容体系の活性化が 重要であることを明らかにした。ささらにCKD 患者にアルドステロン拮抗薬を投与することで インスリン抵抗性の進行およびGFR低下の抑制 をもたらされることを見出だした.

\section{4. 腎臓をターゲットにした「先制医療」の 可能性}

Mets患者において一般的なリスク評価とそれ に基づく生活習慣修正は，もちろん重要である が, その推進は昨今, 医師, 患者双方の“マン ネリズム”を迎えている. 現在, 患者個々人の 臓器障害を超早期に的確に捉えて, 積極的に介
入し病気の進展予防さらに退行, 完治を目指す 医療として,「先制医療 (pre-emptive medicine)」 が脚光を浴びている.

腎蔵は, 老化のペースメーカー臓器であるこ とに鑑み, アルブミン尿やGFRあるいは, 尿細 管障害マーカーや, RIRsを反映するインスリン 抵抗性に注目し, 腎障害を超早期で検出し, 積 極介入する医療姿勢が重要である，また，新た なバイオマーカーの探索が望まれる.

これまでの臨床試験により，レニンアンジオ テン系阻害薬は早期の糖尿病性腎症を退行させ ることができることが示されている. CKD診療 ガイドライン 2013 では, 糖尿病合併高血圧患者 あるいは, 軽度以上のタンパク尿を示す高血圧 CKD患者では 130/80 mmHg未満に厳格に降圧す ることが推奨されており, また第一選択薬とし てレニンアンジオテンシン系阻害薬の使用を薦 めている.

最近我々は, CKDにおいて, 腎機能を司る遺 伝子群にエピジェネテイックス変化が認められ, その結果長期間におよぶ遺伝子機能の変調が生 じることを見出し(“メモリー効果”), この変化 が一過性の強力なレニンアンジオテンシン系抑 制によって解除されることを明らかにした7).

我々は, 高血圧発症に対する先制医療につい て, 動物実験で見出だした, “アンジオテンシン ブロックメモリー”を利用した新しい治療を試 みている。

我々の共同研究者であるJuliusらは, 2006 年, TOROPHY研究において, 高血圧予備軍の患者 にARBを二年間投与するとその後投薬を中止し ても, 少なくとも 2 年間, 高血圧の発症が, ARB 投与群で有意に抑制されることを報告した8).さ らに私たちは一歩すすめて, 高血圧の退行が可 能かどうかを検証した。すなわち, 高血圧を発 症した初診患者 (年齢が 30 歳から 59 歳の本態 性高血圧症患者で, 家族歴を有する (2 親等以内) ステージIの軽症高血圧)に対して，ARBあるい はカルシウム拮抗薬を一年間投与して, 高血圧 
を治療したのち, 休薬し, その後の高血圧の再 発をテレメデイスン技術により正確に把握評価 した (STAR CAST試験). その結果, 残念なが ら, 両群ともに高血圧は再発したが, ARB投与 群の方が, 有意に高血圧の再発に至る期間が長 かったという結果が得られた9)(図 4). すなわち, レニンアンジオテンシン系抑制治療のメモリー 効果一治療記憶の可能性が示された.

critical periodに適切に集中的に治療すればよ り効果的に疾患の発症進展を抑えることができ る可能性があり，このような新しいモードの先 制医療法は今後積極的に試みられるべきである と思う。

著者のCOI (conflicts of interest) 開示: 伊藤 裕; 講演料 (MSD, 武田薬品工業, ノバルティスファーマ), 寄付金 (ア ストラゼネカ, MSD, 協和発醳キリン, サノフィ, 第一三共, 大日本住友製薬, 武田薬品工業, 田辺三菱製薬, 帝人ファー マ, 日本イーライリリー, ファイザー)

\section{文献}

1）伊藤 裕：時空医療—治療記憶」を生かした医療オプショ ン. 日本医事新報 $4655: 29-34,2013$.

2) 伊藤 裕：臟器の時間. 祥伝社新書, 2013.

3) Nakaya $\mathrm{H}$, et al: Temporary treatment of prepubescent rats with angiotensin inhibitors suppresses the develop- ment of hypertensive nephrosclerosis. J Am Soc Nephrol 12 (4) : 659-666, 2001.

4) Ishiguro K, et al: "Pulse" treatment with high-dose angiotensin blocker reverses renal arteriolar hypertrophy and regresses hypertension. Hypertension 53(1) : 83-89, 2009. doi : 10.1161/HYPERTENSIONAHA.108.122721. Epub 2008 Dec 1.

5) Hasegawa K, et al:Renal tubular Sirtl attenuates diabetic albuminuria by epigenetically suppressing Claudin-1 overexpression in podocytes. Nat Med 19(11) : 1496-1504, 2013. doi : 10.1038/nm.3363. Epub 2013 Oct 20.

6) Hasegawa K, et al: The hydrolase DDAH2 enhances pancreatic insulin secretion by transcriptional regulation of secretagogin through a Sirt1-dependent mechanism in mice. FASEB J 27 (6) : 2301-2315, 2013. doi : 10.1096/fj.12226092. Epub $2013 \mathrm{Feb} 21$.

7) Hayashi K, et al:Regression of glomerulosclerosis in response to transient treatment with angiotensin II blockers is attenuated by blockade of matrix metalloproteinase-2. Kidney Int 78 (1) : 69-78, 2010. doi : 10.1038/ki.2010.81. Epub 2010 Apr 7.

8) Julius $\mathrm{S}$, et al; Trial of Preventing Hypertension (TROPHY) Study Investigators : Feasibility of treating prehypertension with an angiotensin-receptor blocker. N Engl J Med 354 (16) : 1685-1697, 2006. Epub 2006 Mar 14.

9) Sasamura H, et al ; STAR CAST investigators: Feasibility of regression of hypertension using contemporary antihypertensive agents. Am J Hypertens 26 (12) : 13811388, 2013. doi : 10.1093/ajh/hpt105. 